\title{
KARAKTERISTIK FISIK, KIMIA DAN ORGANOLEPTIK SABUN CAIR PENCUCI TANGAN HANDMADE BERBAHAN AMPAS SISA KOPI ESPRESSO
}

\author{
Asri Widyasanti'1), Arinda Nur Ariva2) \\ 1) Program Studi Teknik Pertanian, Fakultas Teknologi Industri Pertanian, Universitas Padjadjaran \\ Jl. Raya Bandung Sumedang km 21, Jatinangor 40600 \\ *E-mail: asriwidyasanti@gmail.com
}

\begin{abstract}
Abstrak
Sisa ampas kopi selama ini masih terbatas pemanfaatannya. Biasanya sisa ampas dijadikan sebagai pupuk penambah nutrisi pertumbuhan tanaman dengan media hidroponik, pengusir serangga, pewangi ruangan, dan penghilang bau. Ternyata, ampas bubuk kopi masih bisa dimanfaatkan untuk merawat kulit. Salah satu upaya meningkatkan nilai tambah ampas kopi sisa espresso yaitu dimanfaatkan menjadi bahan sabun pencuci tangan handmade oleh masyarakat binaan CSR Indonesia Power Kamojang POMU. Tujuan penelitian ini adalah untuk mengetahui karakteristik fisika, kimia, dan organoleptik sabun pencuci tangan berbahan sisa ampas kopi espresso. Metode yang digunakan dalam penelitian ini adalah percobaan laboratorium dengan analisis deskriptif. Pengamatan pada sabun cair antara lain sifat kimia, sifat fisik, dan uji organoleptik. Hasil analisis menunjukkan bahwa formulasi sabun pencuci tangan ampas sisa kopi espresso memiliki pH 7,9 dan bobot jenis 1,034 . Hasil uji organoleptik tingkat kesukaan produk sabun cair cuci tangan ampas kopi yang dihasilkan, masing-masing dengan skor untuk: warna $=2,83$ (tidak suka-biasa), kekentalan $=2,83$ (tidak sukabiasa), aroma $=2,83$ (tidak suka-biasa), kesan saat pemakaian/pembusaan $=3,25$ (biasa-suka), dan kesan setelah pemakaian (kesan kesat) = 3,08 (biasa-suka). Teknologi proses pembuatan sabun cair pencuci tangan handmade dengan penambahan sisa ampas kopi espresso selanjutnya dapat terus dikembangkan sehingga dapat diaplikasikan pada skala industri.
\end{abstract}

Kata kunci: Ampas Kopi, Espresso, Pencuci Tangan, Sabun Handmade

\section{Abstract}

The utilization of coffee residue is still limited. The remaining coffee pulp is typically used as fertilizer for plant growth nutrition with hydroponic media, insect repellent, air freshener and deodorizing agent. Apparently, coffee ground pulp can also be used for skin care. One of the attempts being made by the CSR Indonesia Power Kamojang POMU group to increase the added value of espresso coffee residue is to be used as handmade handwash soap. The goal of this research was to determine the physical, chemical, and organoleptic properties of handwash soap made from espresso coffee residue. The method used in this study was a laboratory experiment with descriptive analysis. Observations on liquid soap include chemical properties, physical properties, and organoleptic tests. The results of the study showed esspresso coffee residue handwash soap formulation had $\mathrm{pH} 7.9$ and specific gravity 1.034. Organoleptic test results on preference level for the resulting liquid soap for: color $=2.83$ (dislike-netral), viscosity $=2.83$ (dislike-netral), aroma $=2$, 83 (dislike-netral), impression when using / foaming $=3.25$ (netral-like), and impression after use (impression rough) $=3.08$ (netral-like). With the addition of the remaining espresso coffee residue, the technical process of manufacturing handwash soap continues to be improved so that it can be applied on an industrial scale.

Keywords: Coffee Residue, Espresso, Handwash, Handmade soap

\section{PENDAHULUAN}

Kopi merupakan salah satu dari komoditas ekspor terbesar di Indonesia. Jenis kopi yang terkenal di Indonesia adalah kopi robusta (Coffea canephora) dan arabika (Coffea arabica). Rata-rata produksi kopi di Jawa Barat pada tahun 2014-2018 mencapai 9,736 ton untuk kopi arabika dan 8,1 ton untuk kopi robusta (Dinas Perkebunan Jawa Barat, 2018). 
Ampas kopi merupakan produk samping dari proses penyeduhan kopi asli dengan metode espresso (menggunakan mesin) dan metode brewing (cara manual). Perkembangan industri kopi yang pesat dan menjamurnya berbagai coffee shop semakin meningkat pula jumlah limbah kopi seperti ampas kopi yang terbuang. Tercatat 90\% ampas kopi terbuang tanpa dimanfaatkan kembali. Ampas dapat menjadi sumber pembuangan sampah sehingga menciptakan gas metana. Beberapa cara pemanfaatan ampas kopi adalah biobriket, biopelet, pupuk tanaman, pembersih alat-alat dapur yang kotor, penghilang bau, perawat warna kayu yang kusam, pengharum ruangan, dan produk kecantikan.

Sabun merupakan sediaan pembersih kulit yang dibuat dari proses saponifikasi atua netralisasi dari lemak, minyal, wax, resin, atau asam dengan basa organik atau anorganik tanpa menimbulkan iritasi pada kulit (BSN, 1996). Sabun berkualitas baik dipengaruhi oleh bahan baku yang digunakan. Ampas kopi dapat diolah menjadi bahan baku pembuatan sabun pencuci tangan handmade, sehingga nilai tambah ampas kopi menjadi meningkat. Ampas dipilih menjadi bahan aktif dalam formulasi sabun pencuci tangan, hal ini dikarenakan dalam ampas masih terdapat kandungan senyawa bioaktif berupa senyawa fenolik yaitu asam klorogenat dan kafein (Andline et al., 2013) yang baik untuk kulit.

Ampas kopi juga berpotensi sebagai antibakteri alami dan antijamur (Sousa et.al., 2015). Penelitian yang telah dilakukan terhadap aktivitas antibakteri ekstrak kopi robusta terhadap E. Coli (Tanauma et. al., 2016) dengan konsentrasi $100 \%$ menghasilkan diameter zona hambat sebesar $27 \mathrm{~mm}, S$. Aureus (Yaqin dan Nurmiawati, 2015) dengan konsentrasi minimal sebesar $12,5 \%$ dan daya hambat yang paling efektif adalah dengan konsentrasi 100\%, dan Porphyromonas gingivalis (Chamidah, 2012) pada konsentrasi $100 \%$, 50\%, dan $25 \%$. Berdasar hal yang diuraikan diatas, tujuan dari penelitian ini adalah mengetahui karakteristik fisika, kimia, dan organoleptik sabun pencuci tangan berbahan sisa ampas kopi espresso.

\section{BAHAN DAN METODE}

Penelitian ini dilaksanakan pada bulan Juni hingga Agustus 2020 bertempat di Laboratorium Pasca Panen dan Teknologi Proses Universitas Padjadjaran.

\section{Bahan}

Alat yang digunakan adalah slowcooker, spatula silikon, timbangan analitik, beaker glass $100 \mathrm{ml}$ dan $1000 \mathrm{ml}$, batang pengaduk, pipet tetes, piknometer, $\mathrm{pH}$ meter, gelas piala, pengaduk magnetik.

Bahan yang digunakan adalah minyak kelapa dengan nama dagang Barco dan ampas sisa kopi espresso yang didapat dari Kamojang, Garut. Bahan-bahan kimia yang digunakan diantaranya $\mathrm{KOH} 30 \%$, gliserin, akuades, propilena glikol dan fragrance oil kopi dan sabun handmade kopi merk $X$.

\section{Metode}

Berikut merupakan formulasi pembuatan sabun handwash ampas kopi seperti pada Tabel 1.

Tabel 1. Formulasi pembuatan sabun pencuci tangan ampas kopi esspresso untuk sediaan $500 \mathrm{~g}$ sabun

\begin{tabular}{ccl}
\hline Bahan (g) & & \multicolumn{1}{c}{ Fungsi } \\
\hline $\begin{array}{c}\text { Infused Oil Ampas } \\
\text { Kopi }\end{array}$ & 150 & $\begin{array}{l}\text { Surfaktan, } \\
\text { pengemulsi } \\
\text { dengan } \\
\text { bahan aktif } \\
\text { tambahan }\end{array}$ \\
Kalium Hidroksida & 105 & $\begin{array}{l}\text { Alkali Bebas } \\
\text { (Basa) }\end{array}$ \\
(KOH) $30 \%$ & Humektan \\
Gliserin & 20,5 & Humektan \\
Propilena Glikol & 45 & Pelarut \\
Aquadest & 279,5 & Pewangi \\
\hline
\end{tabular}

\section{Tahapan Penelitian}

Penelitian ini terdiri dari empat tahap, tahapan pertama yaitu persiapan bahan baku yaitu pembuatan larutan $\mathrm{KOH} 30 \%$. Tahapan kedua adalah pembuatan infused oil teh putih dengan metode heat infusions. Tahapan ketiga 
adalah pembuatan sabun cair dimana formulasi pembuatan sabun cair tersebut telah ditentukan terlebih dahulu sehingga dapat menghasilkan karakteristik sabun cair yang sesuai dengan SNI. Tahapan keempat adalah analisa pengujian mutu sabun cair yang dihasilkan sesuai dengan syarat mutu pada SNI diantaranya sifat fisika berupa bobot jenis mengacu pada SNI sabun mandi cair SNI , uji sifat kimia berupa nilai pH (Sabun Pencuci Tangan SNI 2588-2017), selain itu, dilakukan juga pengujian organoleptik.

\section{Persiapan bahan baku}

Persiapan bahan baku dalam pembuatan sabun cair adalah menyiapkan bahan-bahan kimia yang digunakan dalam pembuatan sabun cair dan pembuatan larutan $\mathrm{KOH}$ dengan konsentrasi $30 \% \quad(\mathrm{~b} / \mathrm{v})$ dari bentuk kristal padatannya.

\section{Pembuatan Infused Oil Ampas Kopi}

Pembuatan infused oil ampas kopi dilakukan dengan metode heat infusions dengan menggunakan minyak kelapa. Ekstraksi dengan metode infus dengan perbandingan ampas kopi dan minyak kelapa yang digunakan dengan perbandingan 1: 15 (b/b) dari berat minyak kelapa mengacu pada (Widagyo et.al., 2013) Pembuatan infused oil ampas kopi dapat dilihat dalam diagram alir proses pembuatan infused oil ampas kopi pada

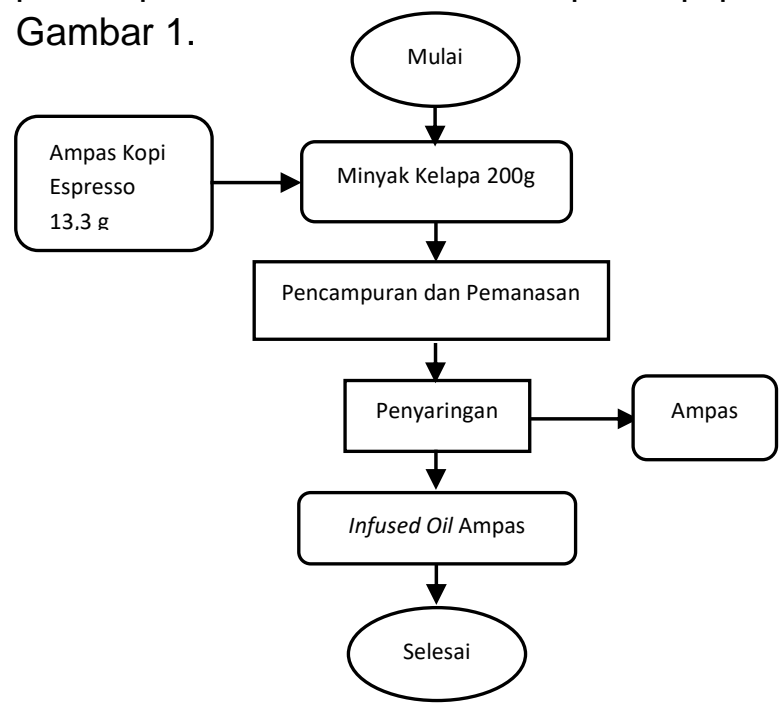

Gambar 1. Diagram alir pembuatan infused oil ampas kopi

\section{Pembuatan Sabun Cair}

Pembuatan sabun cair berbahan baku minyak kelapa ini dilakukan dengan menggunakan metode hot process soap making. Pembuatan sabun cair berbahan baku infused oil ampas kopi dapat dilihat dalam diagram alir proses pembuatan sabun pencuci tangan ampas kopi pada Gambar 2

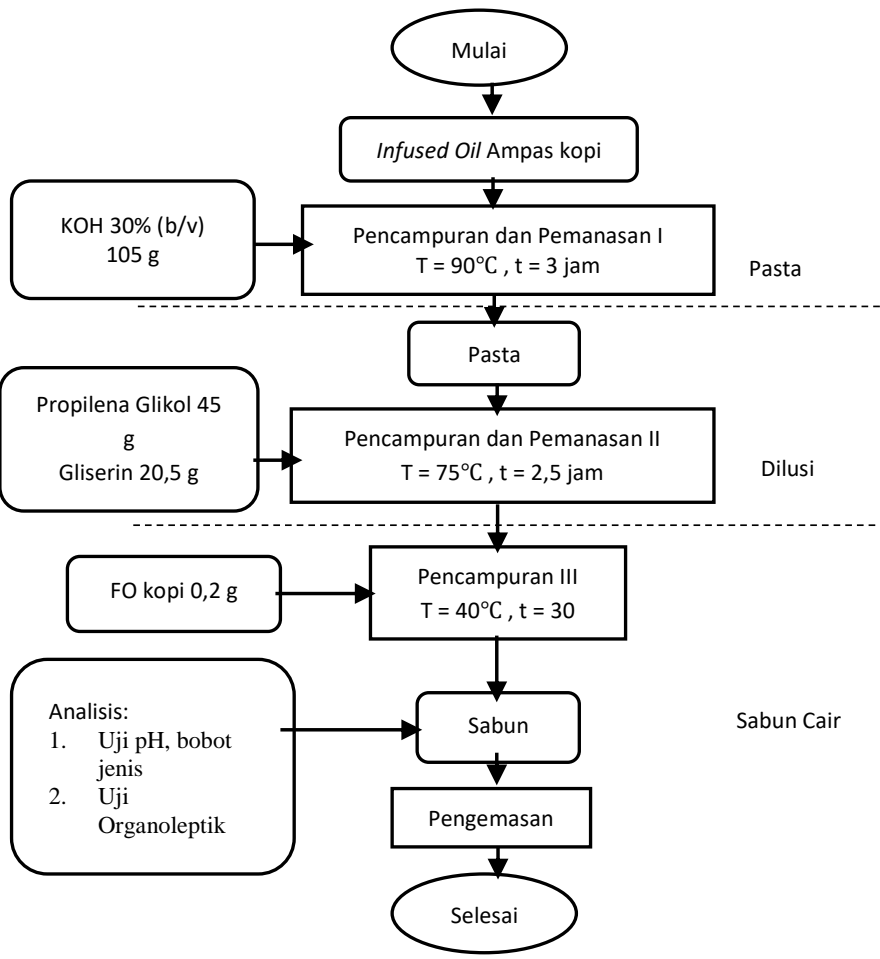

\section{Gambar 2. Diagram alir proses pembuatan} sabun pencuci tangan ampas kopi

4. Pengujian Mutu

Pengujian mutu sabun cair meliputi uji sifat fisik sabun berupa nilai bobot jenis (SNI 064085-1996 tentang sabun cair), uji sifat kimia sabun berupa nilai pH (SNI 2588-2017 tentang sabun pencuci tangan) dan pengujian organoleptik sabun cair meliputi warna, aroma, kekentalan, kesan saat pemakaian, dan kesan setelah pemakaian dan kesukaan secara umum.

\section{Analisis Data}

Parameter yang diamati meliputi rendemen, nilai $\mathrm{pH}$, bobot jenis, dan uji sensoris terhadap warna, aroma, kekentalan, serta kesan saat 
dan setelah pemakaian. Uji sensoris dilakukan dengan uji skoring untuk pembedadaan menggunakan 25 panelis tidak terlatih.

\section{HASIL DAN PEMBAHASAN}

\section{pH Sabun Cair}

Derajat keasaman atau $\mathrm{pH}$ merupakan parameter kimiawi untuk mengetahui sabun cair yang dihasilkan bersifat asam atau basa. $\mathrm{pH}$ merupakan parameter penting pada produk kosmetika, karena nilai $\mathrm{pH}$ dapat mempengaruhi daya absorpsi kulit. Uji pH merupakan salah satu syarat mutu sabun cair. Hal tersebut karena sabun cair kontak langsung dengan kulit dan dapat menimbulkan masalah apabila $\mathrm{pH}$-nya tidak sesuai dengan $\mathrm{pH}$ kulit. Menurut Badan Standardisasi Nasional (BSN, 2017), nilai pH untuk sabun cair pembersih tangan adalah pada rentang 410.

Berdasarkan hasil pengukuran dari kedua sampel memenuhi syarat SNI untuk sabun cair pencuci tangan. Sabun pencuci tangan ampas kopi memiliki pH sebesar 7,9 dan sabun kopi komersil memiliki pH sebesar 8,2. Sabun cair pencuci tangan memiliki kecenderungan bersifat basa karena berbahan dasar $\mathrm{KOH}$ yang bersifat basa kuat. Nilai $\mathrm{pH}$ sabun pencuci tangan ampas kopi lebih rendah dibandingkan dengan nilai $\mathrm{pH}$ sabun kopi komersil karena ampas kopi memiliki sifat asam sehingga menurunkan nilai $\mathrm{pH}$ sabun cair pencuci tangan.

\section{Bobot Jenis}

Bobot jenis merupakan perbandingan bobot suatu zat di udara pada suhu $25{ }^{\circ} \mathrm{C}$ terhadap bobot air dengan volume dan suhu yang sama (Voight, 1994). Nilai bobot jenis pada sabun cair menunjukkan kemampuan suatu zat bercampur dengan zat lainnya. Berdasarkan SNI 06-4085-1996 tentang Sabun Cair, rentang standar bobot jenis sabun cair adalah sekitar 1,01-1,10.

Hasil pengukuran bobot jenis kedua sampel tersebut diketahui nilai bobot jenis untuk sabun cair pencuci tangan ampas kopi adalah 1,0349 dan bobot jenis sabun kopi komersil adalah 1,2656. Jika dibandingkan dengan nilai standar, sabun pencuci tangan ampas kopi sudah memenuhi standar, sedangkan sabun kopi komersil memiliki nilai bobot jenis di atas nilai standar. Faktor yang mempengaruhi nilai bobot jenis adalah kekentalan, semakin kental suatu zat maka nilai bobot jenis akan semakin besar. Pernyataan tersebut menunjukkan bahwa sabun pencuci tangan ampas kopi memiliki kekentalan yang rendah sedangkan sabun kopi komersil memiliki kekentalan yang tinggi.

\section{Uji Organoleptik}

Pengujian organoleptik dilakukan dengan mengamati warna, aroma, kekentalan, kesan saat pemakaian, dan kesan setelah pemakaian menggunakan indera penglihatan, penciuman, dan indera peraba. Uji ini menilai kesukaan panelis terhadap sabun pencuci tangan ampas kopi dan sabun kopi komersil. Tabel 2 menunjukkan rekap hasil pengujian organoleptic pada 25 orang panelis tidak terlatih.

Tabel 2. Rekapitulasi skor uji organoleptik

\begin{tabular}{lccc}
\hline Parameter & $\begin{array}{c}\text { Sabun } \\
\text { Pencuci } \\
\text { Tangan } \\
\text { Ampas } \\
\text { Kopi }\end{array}$ & $\begin{array}{c}\text { Sabun } \\
\text { Kopi } \\
\text { Komersil }\end{array}$ & Keterangan \\
\hline Warna & 2,96 & 2,44 & $\begin{array}{c}\text { Tidak suka- } \\
\text { Biasa }\end{array}$
\end{tabular}

\begin{tabular}{lccc}
\hline Aroma & 3,2 & 3,24 & Biasa-Suka \\
\hline Kekentalan & 2,92 & 3,32 & $\begin{array}{c}\text { Tidak Suka- } \\
\text { Suka }\end{array}$
\end{tabular}

\begin{tabular}{llll}
\hline $\begin{array}{l}\text { Kesan saat } \\
\text { pemakaian }\end{array}$ & 3,36 & 3,2 & Biasa-Suka \\
\end{tabular}

\begin{tabular}{llll}
\hline $\begin{array}{l}\text { Kesan } \\
\text { setelah } \\
\text { pemakaian }\end{array}$ & 3,32 & 3,36 & Biasa-Suka \\
& & & \\
\end{tabular}

Keterangan skala uji organoleptik: 1 = Sangat tidak suka, 2 = Tidak suka, 3 = Biasa, 4 = Suka, 5 = Sangat suka 
Berdasarkan hasil pengamatan panelis, warna dari sabun pencuci tangan ampas memiliki skor lebih tinggi dari sabun kopi komersil. Artinya, warna dari sabun pencuci tangan ampas kopi disukai oleh panelis. Hal ini dikarenakan warna dari sabun pencuci tangan berwarna coklat terang sedangkan sabun kopi komersil berwarna coklat gelap sehingga panelis lebih menyukai warna dari sabun pencuci tangan ampas kopi. Skor untuk parameter aroma, antara sabun pencuci tangan ampas kopi dengan sabun kopi komersil berdekatan, dan skor tertinggi ada pada sabun kopi komersil karena aroma dari sabun kopi komersil sangat khas kopi sedangkan untuk sabun cuci tangan ampas kopi memiliki aroma khas kopi tidak sekuat sabun kopi komersil. Kekentalan sabun kopi komersil memperoleh skor tertinggi karena sabun kopi komersil sangat kental dibuktikan dengan tingginya nilai bobot jenis pada sabun kopi komersil. Kesan saat pemakaian untuk sabun pencuci tangan ampas kopi memiliki skor lebih tinggi karena kekentalan sabun yang ringan dan pembusaan saat pemakaian disukai oleh panelis. Kesan setelah pemakaian pada kedua sampel sabun tidak jauh berbeda, hal ini menunjukkan bahwa kedua sabun tersebut menghasilkan kesan kesat yang disukai oleh panelis. Berdasarkan hasil pengamatan keseluruhan parameter diperoleh nilai kesukaan secara keseluruhan dengan skor tertinggi pada sabun pencuci tangan, yaitu dengan skor 2,8 dan sabun kopi komersil memperoleh skor 2,72. Hasil pengujian organoleptik ini menunjukkan bahwa sabun pencuci tangan ampas kopi disukai oleh panelis.

\section{SIMPULAN}

Proses pembuatan sabun pencuci tangan ampas kopi sisa espresso dilakukan dengan metode hot process soap making pada suhu $70^{\circ} \mathrm{C}-80^{\circ} \mathrm{C}$. Hasil analisis sifat fisikokimia sabun pencuci tangan ampas kopi menunjukkan sabun memiliki sifat kimia dan sifat fisik yang sesuai dengan standar mutu sabun cair SNI 06-4085-1996 dan standar mutu sabun pencuci tangan SNI 2588-2017. Hasil analisis sifat kimia dan fisik adalah bobot jenis pada suhu $25^{\circ} \mathrm{C}$ yaitu 1,034 dan nilai $\mathrm{pH}$ 7,9. Hasil pengujian organoleptik menunjukkan sabun pencuci tangan ampas kopi memiliki tingkat kesukaan yang hampir sama dalam warna, aroma, kekentalan, kesan saat pemakaian dan kesan setelah pemakaian. Respon kesukaan panelis secara umum pada sabun pencuci tangan ampas kopi $(2,80)$ lebih besar dibandingkan sabun kopi komersial $(2,72)$. Hal tersebut menunjukkan formulasi sabun pencuci tangan ampas kopi lebih disukai panelis dan berpotensi untuk dikembangkan menjadi produk dengan nilai tambah tinggi.

\section{DAFTAR PUSTAKA}

Andline, A.A. 2013. Antimicrobial and Antioxidant Activities of MicrowaveAssisted Extracts From Coffee Ground Residue in Chiang Rai Province, Thailand. Skripsi. Tidak dipublikasikan. Institut Pertanian Bogor, Bogor.

Badan Standarisasi Nasional. 1996. Standar Mutu Sabun Mandi Cair. SNI 06-40851996. Dewan Standarisasi Nasional. Jakarta.

Badan Standarisasi Nasional. 2017. Standar Mutu Sabun Pencuci Tangan. SNI 25882017. Dewan Standarisasi Nasional. Jakarta

Chamidah, S. 2012. Daya Antibakteri Ekstrak Biji Kopi Robusta (Coffea canephora) Terhadap Pertumbuhan Porphyromonas gingivalis [Skripsi]. Fakultas Kedokteran Gigi Universitas Jember. Jember.

Dinas Perkebunan Provinsi Jawa Barat. 2018. Statistik Perkebunan Jawa Barat: Angka Sementara 2018. Bandung: Dinas Perkebunan Provinsi Jawa Barat

Hizkia Alesta Tanauma, Gayatri Citraningtyas, Widya Astuty Lolo. 2016. Aktivitas Antibakteri Ekstrak Biji Kopi Robusta (Coffea Canephora) Terhadap Bakteri Escherichia Coli. PHARMACON : Jurnal IImiah Farmasi UNSRAT. 5( 4): 243-251

Sousa, C., Gabriel, C., Cerqueira, F., Manso, M., and Vinha, A. 2015. Coffee industrial waste as a natural source of bioactive 
Widyasanti \& Ariva. 2020

Vol. 4, No. 2, 2020

compounds with antibacterial and antifungal activities. Formatex: 131-36.

Voigt, R. 1994. Buku Pelajaran Teknologi Farmasi. Yogyakarta: Gadjah Mada University Press.

Widagyo, D.R., Budiman, V.A., Aylianawati, Indraswati, N. 2013. Ekstraksi Kafein dari Serbuk Kopi Java Robusta dengan Pelarut Minyak Jagung. Jurnal Widya Teknik, 12(1): 1-10

Yaqin, M.A., M. Nurmilawati. 2015.Pengaruh Ekstrak Kopi Robusta (Coffea robusta) sebagai Penghambat Pertumbuhan. Seminar Nasional XII Pendidikan Biologi FKIP UN 